\title{
COMPARATIVE EFFICACY OF PURPLE NUTSEDGE ALLELOPATHY AND OTHER METHODS ON WEED MANAGEMENT IN BARLEY (HORDEUM VULGARE L.)
}

\author{
Muhammad Saleem Chang* ${ }^{1}$, Muhammad Nawaz Kandhro ${ }^{2}$, Zulfiqar Ali Abbasi ${ }^{4}$, \\ Jay Kumar Sootaher* ${ }^{3}$, Piar Ali Shar ${ }^{3}$, Kashif Ali Buriro $^{2}$, Nadia Mangrio ${ }^{5}$, Zafarullah \\ Channa $^{3}$
}

DOI: $\underline{\text { https://doi.org/10.28941/pjwsr.v27i2.893 }}$

\begin{abstract}
This research was carried out in order to compare the impact of purple nutsedge allelopathy and other approaches on weed management in barely at Students' Experimental Farm, Department of Agronomy, Sindh Agriculture University, Tandojam for weed as well as barely parameters having eight treatments with three replications. The data revealed that the maximum weed control $(91.3 \%)$ was recorded under $\mathrm{T}_{7}=$ Puma super $7.5 \%$ emulsifiable water at 0.625 liters ha-1, 50\% reduced (30 Days after sowing) + Purple nutsedge water extract at 15 liters $\mathrm{ha}^{-1}$ (45 Day after sowing). The barley crop's results revealed that maximum tillers $\left(355.6 \mathrm{~m}^{-2}\right)$, plant height $(106.3 \mathrm{~cm})$, spike length $(11.5 \mathrm{~cm})$, grains spike ${ }^{-2}$ (47.3), seed index $(51 \mathrm{~g})$, biological yield $\left(11737 \mathrm{~kg} \mathrm{ha}^{-1}\right)$, grain yield $\left(4493 \mathrm{~kg} \mathrm{ha}^{-1}\right)$ and harvest index $(41.9 \%)$ were recorded under $\mathrm{T}_{7}=$ Puma super $7.5 \%$ emulsifiable water at 0.625 liters ha $^{-1} 50 \%$ reduced (30 Days after sowing) + Purple nutsedge water extract at 15 liters ha ${ }^{-1}$ (45 Days after sowing). Hence, it was suggested that application of puma super $7.5 \%$ emulsifiable water at 0.625 liters ha $^{-1}, 50 \%$ reduced (30 Days after sowing) + Purple nutsedge water extract at 15 liters ha $^{-1}$ (45 Days after sowing) apply for getting higher yield (4493 $\mathrm{kg} \mathrm{ha}^{-1}$ ) of barley crop. It was finalized that this study will be very fruitful for the future progress of barley yield.
\end{abstract}

Keywords: Allelopathy, Barley, Comparative efficacy, Purple nutsedge, Weed management

Citation: Change, M.S. M.N. Kandhro, Z.A. Abbasi, J.K. Sootaher, K.A. Buriro, Z. Channa, N. Mangrio. 2021. Comparative Efficacy of Purple Nutsedge Allelopathy and Other Methods on Weed Management in Barley (Hordeum Vulgare L.). Pak. J. Weed Sci. Res., 27 (2):127-137.

\footnotetext{
${ }^{1}$ Department of Agronomy, Subcampus Umerkot, Sindh Agriculture University, Tandojam, Sindh, Pakistan

${ }^{2}$ Department of Agronomy, Sindh Agriculture University, Tandojam, Sindh, Pakistan

${ }^{3}$ Department of Plant Breeding and Genetics, Sindh Agriculture University, Tandojam, Sindh, Pakistan

${ }^{4}$ Department of Agronomy, Shaheed Zulfiqar Ali Bhutto Agricultural College, Dokri, Sindh, Pakistan

${ }^{5}$ Sugar Research Institute, Tandojam, Sindh, Pakistan

*Corresponding author: mschang@sau.edu.pk; jaykumar3030@gmail.com
} 


\section{INTRODUCTION}

In cereals, barley is an important cereal crop which ranks fourth by production and fifth by cultivation all over the world (Thalooth et al., 2012). The crop is used mainly for animal feed and is also considered as salinity as well as drought tolerant crop. It is also utilised in the manufacture of bread and other foods and drinks for humans. It can perform better in adverse condition as well as in rainfed areas (Kamali et al., 2014). A large number of living and non-living factors have been observed for the decrease in the yield of cereals, but of them, weeds tops in it. Due to this cause, weeds bring an imbalance in the ecosystem in the field of agriculture (Ross and Lembi 2008).

Molisch was the first scientist who defined the term allelopathy in 1937 as the chemical interaction between plants and microorganism. But in 1984, rice changed the definition with all direct effects of a plant on another plant or on a microorganism owing to the release of biochemicals into the environments. Currently, allelopathy internationally is known as any process in which plants, fungi, algae or bacteria generated secondary metabolites for impacting the agricultural and biological system growth and development.

Allelopathy is very beneficial for us; this is why, it has ability to be dominant over the effects of weeds in the control of field crops (Jabran et al., 2015). Allelopathy is also utilized as growth regulators in the form of allelochemicals which has been of a great interest ( $\mathrm{He}$ et al., 2019). Allelochemicals are regards as the best materials in the form of compounds which mainly emerge from unsuitable plants (Cheema et al., 2003 and Hamayun et al. (2005). On the other hand, negative effects of allelopathy had been discussed upon seed germination and crop growth and development (Belel and Belel, 2015). Purple nutsedge is a kind of a weed which harms crops a lot. Approximately, 52 crops have been reported invaded by this weed in 92 countries of the world (Rao, 2000; Chris et al., 2003).

In our homeland, a number of crops have been studied for allelopathy which had articulated positive responses to crops in favour of agriculture. In Sindh, crops are manually, mechanically and chemically protected against weeds (Chachar et al., 2009).

Therefore, this investigation was put into practice to study the effect of purple nutsedge (a weed) allelopathy, manual and chemical methods on weed suppression and enhancement of barley yield and to find out the best treatment for effective weed control and maximum yield of barley.

\section{MATERIALS AND METHODS}

This research was carried out in order to compare the impact of purple nutsedge allelopathy and other approaches on weed management in barely at Students' Experimental Farm, Department of Agronomy, Sindh Agriculture University, Tandojam having eight treatments with three replications during winter season of 2017-2018. The plot size was kept as $5 \times$ $3 \mathrm{~m}\left(15 \mathrm{~m}^{2}\right)$. The treatments included.

\section{$\mathbf{T}_{1}=$ No weeding (control)}

In this treatment, no application of weedicide and weeding was used.

$\mathbf{T}_{\mathbf{2}}=$ Purple nutsedge water extract at 15 liters ha-1 (30 DAS)

In this treatment, 15 liters of purple nutsedge extract was used as an aqueous solution per hectare after 30 days of sowing.

$T_{3}=$ Purple nutsedge water extract at 15 liters ha-1 (30 and 45 DAS)

In this treatment, 15 liters of purple nutsedge extract was used as an aqueous solution per hectare after 30 and 45 days of sowing.

$\mathbf{T}_{4}=$ Purple nutsedge water extract at 20 liters ha-1 (30 DAS)

In this treatment, 20 liters of purple nutsedge extract was used as an aqueous solution per hectare after 30 days of sowing.

$\mathbf{T}_{5}=$ Purple nutsedge water extract at 20 liters ha-1 (30 and 45 DAS)

In this treatment, 20 liters of purple nutsedge extract was used as an aqueous 
solution per hectare after 30 and 45 days of sowing.

$T_{6}=$ Puma super $7.5 \%$ EW at 1.25 liters ha ${ }^{-1}$ (30 DAS)

In this treatment, 1.25 liters of puma super $7.5 \%$ was used as an emulsifiable water per hectare after 30 days of sowing.

$\mathbf{T}_{7}=$ Puma super $7.5 \% \mathrm{EW}$ at 0.625 liters ha-1 (30 DAS) + Purple nutsedge water extract at $15 \mathrm{~L} \mathrm{ha}^{-1}$ (45 DAS)

In this treatment, 0.625 liters of puma super $7.5 \%$ and 15 liters of purple nutsedge were together used as an emulsifiable water and an aqueous solution per hectare after 30 and 45 days of sowing.

$\mathbf{T}_{8}=$ Hand weeding ( 30 and 45 DAS)

In this treatment, two hand weedings were practiced after 30 and 45 days of sowing.

\section{Observations were recorded:}

1. Weed flora: All infesting weed species were recorded and their local names, botanical names and families are mentioned.

2. Weed density $\left(\mathbf{m}^{-2}\right)$ : The weeds were counted at 60 DAS by using wooden frame of one square meter in all plots of each treatment at one location and calculated as $\left(\mathrm{m}^{-2}\right)$. It was estimated according to formula given by Gupta (1998).

$$
W D\left(\mathrm{~m}^{-2}\right)=\frac{\text { Tt No. of weeds }}{\text { Number of repilication }}
$$

3. Weed fresh weight $\left(\mathrm{g} \mathrm{m}^{-2}\right)$ : Weeds fresh weight was taken from randomly selected areas of one meter square at one stage at 60 DAS.

4. Weed dry weight $\left(\mathrm{g} \mathrm{m}^{-2}\right)$ : Weeds dry weight sample taken for fresh weight was dried at 70

${ }^{\circ} \mathrm{C}$ for 72 hours.

5. Weed control (\%): It was calculated according to Mani et al. (1973)

$$
W C=\frac{W C D-G T D}{\text { Weed check density }} \times 100
$$

6. Tillers $\left(\mathbf{m}^{-2}\right)$ : From each selected plant, tillers meter ${ }^{-1}$ was counted.

7. Plant height $(\mathbf{c m})$ : At maturity, the height of plants was taken from bottom to top with the assistance of measurement tape.

8. Spike length $(\mathbf{c m})$ : The length of spikes was taken by using inch tape.
9. Grains spike ${ }^{-1}$ : Spikes were threshed and number of grains were counted.

10. Seed index (1000 grains weight, g): After threshing the experimental crop for each plot separately, the 1000 grains from each plot were taken and weighed by electronic top loading balance in grams.

11. Biological yield $\left(\mathbf{k g} \mathbf{h a}^{-\mathbf{1}}\right)$ : After maturity and harvest of the crop, following formula was put into practice according to Inamullah et al. (2011).

$$
B Y\left(\mathrm{~kg} \mathrm{ha}^{-1}\right)=\frac{B Y\left(\mathrm{plot}^{-1}\right)}{\text { Plot size }\left(\mathrm{m}^{-1}\right)} \times 10,000
$$

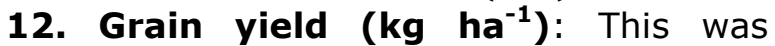
calculated formula of Inamullah et al. (2011).

$$
G Y\left(\mathrm{~kg} \mathrm{ha}^{-1}\right)=\frac{G Y\left(\mathrm{plot}^{-1}\right)}{\text { Plot size }\left(\mathrm{m}^{-1}\right)} \times 10,000
$$

13. Harvest index: It was calculated according the formula given by Reddy (2004).

\section{Statistical analysis}

$$
H I(\%)=\frac{G Y\left(k g h a^{-1}\right)}{B Y\left(k g h a^{-1}\right)} \times 100
$$

Collected data were brought under the statistical analysis by using Statistix. 8.1 2006. ANOVA was computed as suggested by Gomez and Gomez (1984) and he least significant difference test was applied according to the methods developed by Steel and Torrie (1960) to compare treatments superiority

\section{RESULTS AND DISCUSSION Weed flora}

Weed flora as affected by comparative efficacy of purple nutsedge allelopathy and other methods on weed management in barley crop are given in Table 1. Following narrow and broad leaf weeds were present in experiment area. 
Table 1. Weed flora of barley as affected by purple nutsedge allelopathy and other methods

\begin{tabular}{|c|c|c|c|}
\hline Local name & English name & Botanical name & Weed frequency (\%) \\
\hline Jhil & Lamb's squarter & Chenopodium album L. & 8 \\
\hline Sinjh & White sweet clover & Melilotus alba L. & 7 \\
\hline Jangli javi & Wild oat & Avena fatua L. & 25 \\
\hline Dumbi sati & Little canarygrass & Phalaris minor (Retz.) & 4 \\
\hline Kabah & Purple nutsedge & Cyprus rotundus L. & 11 \\
\hline Chabbar & Bermuda grass & Cynodon dictylon L. & 6 \\
\hline Naro & Field bind weed & Convolvulus arvensis L. & 10 \\
\hline Basri & Wild onion & $\begin{array}{c}\text { Asphodelius tenuifolius } \\
\text { L. }\end{array}$ & 8 \\
\hline Peeli sinjh & Indian clover & Melilotus indica L. & 6 \\
\hline Jangli palak & $\begin{array}{c}\text { Dock broad } \\
\text { Leaf }\end{array}$ & Rumex dentatus L. & 2 \\
\hline
\end{tabular}

\section{Weed number $\left(\mathrm{m}^{-2}\right)$}

The result showed that maximum weed number $\left(45.6 \mathrm{~m}^{-2}\right)$ was recorded under no weeding (control) followed by $\left(33.6 \mathrm{~m}^{-2}\right)$ under Purple nutsedge water extract at $15 \mathrm{~L} \mathrm{ha}^{-1}$ (30 DAS). Whereas, the minimum weed number was observed under $\left(8.0 \mathrm{~m}^{-2}\right)$ Puma super $7.5 \% \mathrm{EW}$ at $0.625 \mathrm{~L} \mathrm{ha}^{-1}, 50 \%$ reduced (30 DAS) + Purple nutsedge water extract at $15 \mathrm{~L} \mathrm{ha}^{-1}$ (45 DAS) and $\left(10.6 \mathrm{~m}^{-2}\right.$ ) Hand weeding (30 and 45 DAS), respectively. Such results were also informed by Tawaha et al. (2002). Many weeds are present in the field which threaten plants and make trouble for a sustainable production (Zohary et al., 2012). The same findings have been reported by Jabran (2017) and he advised that weeds may be reduced by planting these highly allopathic cultivars.

\section{Weed fresh weight $\left(\mathrm{g} \mathrm{m}^{-2}\right)$}

The result directed that the highest fresh weight $\left(20.6 \mathrm{~g} \mathrm{~m}^{-2}\right.$ ) was verified under No weeding (control) followed by $\left(16.3 \mathrm{~g} \mathrm{~m}^{-2}\right)$ under Purple nutsedge water extract at $15 \mathrm{ha}^{-1}$ (30 DAS). However, the least weed fresh weight $\left(5.6 \mathrm{~g} \mathrm{~m}^{-2}\right.$ and 7.6 $\mathrm{g} \mathrm{m}^{-2}$ ) was noted under Puma super $7.5 \%$
EW at $0.625 \mathrm{~L} \mathrm{ha}^{-1}, 50 \%$ reduced (30 DAS) + Purple nutsedge water extract at $15 \mathrm{~L} \mathrm{ha}^{-1}$ (45 DAS) and Hand weeding (30 and 45 DAS), respectively (Table 2 ). Weed resistance also studied by Heap (2013). Weston and Duke (2003) and Raghvendra et al. (2016) who emphasized that allelopathy could the most promising tool for substantial production by supressing the weed growth and prevention of weed resistance to toxic chemical herbicides.

\section{Weed dry weight $\left(\mathrm{g} \mathrm{m}^{-2}\right)$}

The results showed that the most weed dry weight $\left(6.3 \mathrm{~g} \mathrm{~m}^{-2}\right)$ was documented under No weeding (control) followed by $\left(5.6 \mathrm{~g} \mathrm{~m}^{-2}\right.$ ) under Purple nutsedge water extract at $15 \mathrm{~L} \mathrm{ha}^{-1}$ (30 DAS), whereas the least weed dry weight $\left(2.6 \mathrm{~g} \mathrm{~m}^{-2}\right)$ was noted under Puma super $7.5 \% \mathrm{EW}$ at $0.625 \mathrm{~L} \mathrm{ha}^{-1}, 50 \%$ reduced (30 DAS) + Purple nutsedge water extract at $15 \mathrm{~L} \mathrm{ha}^{-1}$ (45 DAS) and Puma super 75 EW at $1.25 \mathrm{~L} \mathrm{ha}^{-1}$ (30 DAS) $\left(3.30 \mathrm{~g} \mathrm{~m}^{-2}\right.$ ) and Hand weeding (30 ad 45 DAS) ( $3.30 \mathrm{~g}$ $\mathrm{m}^{-2}$ ), respectively (Table 2 ). Weed impact can be reduced by applying integrated weed management so as to save plants from damage (Monaco et al., 2002). Our 
results were in agreement with Hansen (2007). The final finding was in agreement with Kandhro et al. (2016), who found that weeds interfere not only with crop plant, but also with allelopathy.

\section{Weed control (\%)}

The results presented that more weed control (91.3\%) was noticed in Puma super $7.5 \%$ EW at $0.625 \mathrm{~L} \mathrm{ha}^{-1}$, $50 \%$ reduced (30 DAS) + Purple nutsedge water extract at $15 \mathrm{~L} \mathrm{ha}^{-1}$ (45 DAS) followed by $(85.0 \%)$ under Hand weeding (30 and 45 DAS), yet the lowest weed control $(00.00 \%)$ was observed in No weeding (control) and Purple nutsedge water extract at $15 \mathrm{~L} \mathrm{ha}^{-1}$ (30 DAS) (52.3 $\%)$, respectively. Biotic and abiotic factors decline cereal production in which the weed has been the most important factor (Rose and Lembi, 2008). Significant effect of treatments was also discovered by Didar and Ali (2016) on a wide range of physio-morphological attributes.

\section{Tillers $\left(\mathrm{m}^{-2}\right)$}

The result displayed that more tillers $\left(355.6 \mathrm{~m}^{-2}\right)$ were estimated under $\mathrm{T}_{7}=$ Puma super $7.5 \% \mathrm{EW}$ at $0.625 \mathrm{~L} \mathrm{ha}^{-1}$, $50 \%$ reduced (30 DAS) + Purple nutsedge water extract at $15 \mathrm{~L} \mathrm{ha}^{-1}$ (45 DAS) followed by $\left(315.0 \mathrm{~m}^{-2}\right)$ under $\mathrm{T}_{8}=$ Hand weeding (30 and 45 DAS). On the other hand, less tillers $\left(235.0 \mathrm{~m}^{-2}\right)$ were assessed under $\quad \mathrm{T}_{1}=$ No weeding (control) and $T_{2}=$ Purple nutsedge water extract at $15 \mathrm{~L} \mathrm{ha}^{-1}$ (30 DAS) $\left(\left(260.3 \mathrm{~m}^{-2}\right)\right.$ (Table 3). Stimulatory and inhibitory effects of allelochemicals rely upon the concentration of allelochemical compounds (Bhowmik and Inderjiit, 2003). Barley is very tolerant due to the presence of better performance in adverse agro climatic conditions (Kamali et al., 2014). Further favouring allelopathy, Arif et al. (2015) defined allelopathy as both a companion and an organic weed-control technique.

\section{Plant height (cm)}

The result revealed that the tallest plants $(106.3 \mathrm{~cm})$ were reported in $T_{7}=$ Puma super $7.5 \%$ EW at $0.625 \mathrm{~L} \mathrm{ha}^{-1}$, $50 \%$ reduced (: 30 DAS) + Purple nutsedge water extract at $15 \mathrm{~L} \mathrm{ha}^{-1}$ (45 DAS) followed by $(99.0 \mathrm{~cm})$ under $T_{8}=$ Hand weeding (30 and 45 DAS). While, the most dwarf plants $(60.9 \mathrm{~cm}$ and 70.5 $\mathrm{cm}$ ) were demonstrated in $\mathrm{T}_{1}=$ No weeding (control) and $\mathrm{T}_{2}=$ Purple nutsedge water extract at $15 \mathrm{~L} \mathrm{ha}^{-1}$ (30 DAS), respectively (Table 3 ). It was suggested that the weeds are a big source of allelochemicals having the ability to alter the rhizospheric system of nearby plants in the field (Cheema et al., 2003). In the experiment of El-Rokiek et al. (2010) Imen et al. (2014), barley varieties and landraces articulated different allelopathic activities on weeds.

\section{Spike length $(\mathrm{cm})$}

The result exhibited that the longest spikes $(11.5 \mathrm{~cm})$ were expressed under $\mathrm{T}_{7}=$ Puma super $7.5 \% \mathrm{EW}$ at 0.625 $\mathrm{L} \mathrm{ha}^{-1}, 50 \%$ reduced (30 DAS) + Purple nutsedge water extract at $15 \mathrm{~L} \mathrm{ha}^{-1}$ (45DAS) followed by $(10.4 \mathrm{~cm})$ under $\mathrm{T}_{8}=$ Hand weeding (30 and 45 DAS), nevertheless the shortest spikes $(7.1 \mathrm{~cm}$ and $8.8 \mathrm{~cm}$ ) were presented in $\mathrm{T}_{1}=$ No weeding (control) as well as in $\mathrm{T}_{2}=$ Purple nutsedge water extract at $15 \mathrm{~L} \mathrm{ha}^{-1}$ (30 DAS). The length of a spike is very vital character to increase the yield of the crop. The worst weed in the globe is Purple nutsedge which is scattered in 52 crops and 92 countries (Rao, 2000). According to Rasmussen (1991) and Khaliq et al. (2011), weed suppression has many benefits acquired by sol incorporation of crop residues and such suppression is believed to be allelopathic in nature.

\section{Seed index (1000-grain weight)}

The result showed that the maximum seed index $(51.0 \mathrm{~g})$ was recorded in $\mathrm{T}_{7}=$ Puma super $7.5 \% \mathrm{EW}$ at $0.625 \mathrm{~L} \mathrm{ha}^{-1}, 50 \%$ reduced (30 DAS) + Purple nutsedge water extract at $15 \mathrm{~L} \mathrm{ha}^{-1}$ (45 DAS) followed by $(48.6 \mathrm{~g})$ in $\mathrm{T}_{6}=$ Puma super $7.5 \%$ EW at $1.25 \mathrm{ha}^{-1}$ (30 DAS), nonetheless the lowest seed index $(36.0 \mathrm{~g})$ was detected under $\mathrm{T}_{1}=$ No weeding (control) and $\mathrm{T}_{2}=$ Purple nutsedge water extract at $15 \mathrm{~L} \mathrm{ha}^{-1}$ (30 DAS) (39.6 g), respectively (Table 3 ). 
Preventive methods in the form of organic weed management (Beberi, 2002) like crop retention (Bond and Grundy, 2001), application of fertilizers (Rasmussen, 1991) and cultivation of resistant species and varieties (Lemerle et al., 2001) have been able to control the weeds, whereas curative methods namely weed harrowing during pre and post emergence in the same form have also been very advantageous for the maintenance of the weed population (Kurstiens and Kropff, 2001). Cheema et al. (2003) did an experiment on weeds and informed about them that they were a bid source of allelochemical.

\section{Biological yield $\left(\mathrm{kg} \mathrm{ha}^{-1}\right)$}

Biological and grain yield are two important characters. Biological yield is the total weight of a plant, whereas grain yield is defined as the total weight of number of grains per plant. The result exposed that more biological yield (11737 $\mathrm{kg} \mathrm{ha}^{-1}$ ) was documented under $\mathrm{T}_{7}=$ Puma super $7.5 \%$ EW at $0.625 \mathrm{~L} \mathrm{ha}^{-1}, 50 \%$ reduced (30 DAS) + Purple nutsedge water extract at $15 \mathrm{~L} \mathrm{ha}^{-1}$ (45 DAS) followed by $(10720 \mathrm{~kg}$ $\mathrm{ha}^{-1}$ ) in $\mathrm{T}_{6}=$ Puma super $7.5 \% \mathrm{EW}$ at 1.25 $\mathrm{L} \mathrm{ha}^{-1}$ (30 DAS). While, the least biological yield ( $5500 \mathrm{~kg} \mathrm{ha}^{-1}$ ) was witnessed in $\mathrm{T}_{1}=$ No weeding (control) and under $\mathrm{T}_{2}=$ Purple nutsedge water extract at $15 \mathrm{~L} \mathrm{ha}^{-1}$ (30 DAS) (5782 kg ha-1) (Table 3). Current results were also in agreement with Bryson et al. (2003) and Chachar et al. (2009) who used chemical method for the control of weeds and allelopathy activity.

\section{Grain yield $\left(\mathrm{kg} \mathrm{ha}^{-1}\right)$}

The result disclosed that the maximum grain yield $\left(4493.00 \mathrm{~kg} \mathrm{ha}^{-1}\right)$ was observed under $\mathrm{T}_{7}=$ Puma super $7.5 \% \mathrm{EW}$ at $0.625 \mathrm{~L} \mathrm{ha}^{-1}, 50 \%$ reduced (30 DAS) + Purple nutsedge water extract at $15 \mathrm{~L} \mathrm{ha}^{-1}$ (45 DAS) followed by (4335.0 $\mathrm{kg} \mathrm{ha}^{-1}$ ) under $\mathrm{T}_{8}=$ Hand weeding (30 and 45 DAS), however the minimum grain yield (1936.6 kg ha-1) was perceived under $\mathrm{T}_{1}=$ No weeding (control) and $\mathrm{T}_{2}=$ Purple nutsedge water extract at $15 \mathrm{~L} \mathrm{ha}^{-1}$ (30 DAS) (2156.6 $\mathrm{kg} \mathrm{ha}^{-1}$ ), respectively (Table 3 ). Such results had also been articulated by Cheema et al. (2003) and Kremer and Ben-Hammouda (2009). A limited number of allelochemicals contributing allelopathic effectiveness on barely were also identified by Robert and Hammouda (2009).

\section{Harvest index (\%)}

The result showed that the maximum harvest index (41.9\%) was verified under $\mathrm{T}_{8}=$ Hand weeding (30 and 45 DAS) followed by $(39.9 \%)$ under $\mathrm{T}_{6}=$ Puma super $7.5 \%$ EW at $1.25 \mathrm{~L} \mathrm{ha}^{-1}$ (30 DAS), nonetheless the minimum harvest index $(26.0 \%$ and $32.3 \%)$ was notified in $\mathrm{T}_{3}=$ Purple nutsedge water extract at $15 \mathrm{~L}$ $\mathrm{ha}^{-1}$ (30 and 45 DAS) and $\mathrm{T}_{5}=$ Purple nutsedge water extract at $20 \mathrm{~L} \mathrm{ha}^{-1}$ (30 and 45 DAS), respectively (Table 3 ). Good effects of allelopathy were also obtained by Kong et al. (2006) and Murimwas et al. (2019) 
Table 2. Different weed observations of barley as affected by purple nutsedge allelopathy and other methods

\begin{tabular}{|c|c|c|c|c|}
\hline Treatments & $\begin{array}{c}\text { Weed } \\
\text { number } \\
\left(\mathbf{m}^{-2}\right)\end{array}$ & $\begin{array}{l}\text { Weed fresh } \\
\text { weight } \\
\left(\mathrm{g} \mathrm{m}^{-2}\right)\end{array}$ & $\begin{array}{l}\text { Weed dry } \\
\text { weight } \\
\left(g^{-2}\right)\end{array}$ & $\begin{array}{l}\text { Weed } \\
\text { control } \\
(\%)\end{array}$ \\
\hline $\mathrm{T}_{1}$. No weeding (control) & 45.6 & 20.6 & 6.3 & 0.0 \\
\hline $\begin{array}{l}\mathrm{T}_{2} \text {. Purple nutsedge water extract } \\
\left.\text { at } 15 \mathrm{~L} \mathrm{ha}^{-1} \text { ( } 30 \mathrm{DAS}\right)\end{array}$ & 33.3 & 16.3 & 5.6 & 52.3 \\
\hline $\begin{array}{l}\mathrm{T}_{3} \text {. Purple nutsedge water extract } \\
\text { at } 15 \mathrm{~L} \mathrm{ha}^{-1} \text { ( } 30 \text { and } 45 \text { DAS) }\end{array}$ & 29.0 & 12.6 & 4.3 & 73.0 \\
\hline $\begin{array}{l}\mathrm{T}_{4} \text {. Purple nutsedge water extract } \\
\left.\text { at } 20 \mathrm{~L} \mathrm{ha}^{-1} \text { ( } 30 \mathrm{DAS}\right)\end{array}$ & 22.6 & 14.3 & 4.6 & 65.3 \\
\hline $\begin{array}{l}T_{5} \text {. Purple nutsedge water extract } \\
\left.\text { at } 20 \mathrm{~L} \mathrm{ha}^{-1} \text { ( } 30 \text { and } 45 \mathrm{DAS}\right)\end{array}$ & 15.0 & 9.0 & 4.0 & 76.3 \\
\hline $\begin{array}{l}\mathrm{T}_{6} \text {. Puma super } 7.5 \% \mathrm{EW} \text { at } 1.25 \\
\mathrm{~L} \mathrm{ha}^{-1} \text { ( } 30 \text { DAS) }\end{array}$ & 11.0 & 8.0 & 3.3 & 83.0 \\
\hline $\begin{array}{l}T_{7} \text { Puma super } 7.5 \% \text { EW at } 0.625 \\
L \mathrm{ha}^{-1}, 50 \% \text { reduced ( } 30 \text { DAS) }+ \\
\text { Purple nutsedge water extract at } \\
\left.15 \mathrm{~L} \mathrm{ha}^{-1} \text { ( } 45 \mathrm{DAS}\right)\end{array}$ & 8.0 & 5.6 & 2.6 & 91.3 \\
\hline $\begin{array}{l}\text { T. Hand weeding (30 and } 45 \\
\text { DAS) }\end{array}$ & 10.6 & 7.6 & 3.3 & 84.0 \\
\hline $\mathrm{SE} \pm$ & 1.0983 & 0.8286 & 0.5156 & 1.0370 \\
\hline LSD 0.05 & 2.3557 & 1.7771 & 1.1059 & 2.2242 \\
\hline CV \% & 6.14 & 8.61 & 14.71 & 1.93 \\
\hline
\end{tabular}


Table 3. Different barley observations as affected by purple nutsedge allelopathy and other methods

\begin{tabular}{|c|c|c|c|c|c|c|c|c|}
\hline Treatments & $\begin{array}{l}\text { Tillers } \\
\left(\mathbf{m}^{-2}\right)\end{array}$ & $\begin{array}{c}\text { Plant } \\
\text { height } \\
(\mathbf{c m})\end{array}$ & $\begin{array}{c}\text { Spike } \\
\text { length } \\
(\mathrm{cm})\end{array}$ & $\begin{array}{c}\text { Grain } \\
\text { spike }^{-1}\end{array}$ & $\begin{array}{c}\text { Seed } \\
\text { index }(g)\end{array}$ & $\begin{array}{c}\text { Biological } \\
\text { yield } \\
\left(\mathbf{k g ~ h a}^{-1}\right)\end{array}$ & $\begin{array}{c}\text { Grain yield } \\
\left(\mathrm{kg} \mathrm{ha}^{-1}\right)\end{array}$ & $\begin{array}{c}\text { Harvest } \\
\text { index } \\
(\%)\end{array}$ \\
\hline $\mathrm{T}_{1}$. No weeding (control) & 235.0 & 60.9 & 7.1 & 23.0 & 36.0 & 5500 & 1936.6 & 35.2 \\
\hline $\begin{array}{l}\mathrm{T}_{2} \text {. Purple nutsedge water extract at } \\
15 \mathrm{~L} \mathrm{ha}^{-1} \text { (30 DAS) }\end{array}$ & 260.3 & 70.5 & 8.8 & 29.3 & 39.6 & 5782 & 2156.7 & 37.4 \\
\hline $\begin{array}{l}\mathrm{T}_{3} . \text { Purple nutsedge water extract at } \\
15 \mathrm{~L} \mathrm{ha}^{-1} \text { (30 and } 45 \text { DAS) }\end{array}$ & 284.3 & 87.3 & 9.8 & 35.0 & 46.3 & 9273 & 2415.9 & 26.0 \\
\hline $\begin{array}{l}\text { T4. Purple nutsedge water extract at } \\
\left.20 \mathrm{~L} \mathrm{ha}^{-1} \text { ( } 30 \mathrm{DAS}\right)\end{array}$ & 272.0 & 84. 0 & 9.12 & 30.0 & 43.0 & 8055 & 2733.1 & 34.1 \\
\hline $\begin{array}{l}T_{5} \text {. Purple nutsedge water extract at } \\
20 \mathrm{~L} \mathrm{ha}^{-1}(30 \text { and } 45 \text { DAS) }\end{array}$ & 293.6 & 91.0 & 9.9 & 38.6 & 47.3 & 10357 & 3348.3 & 32.3 \\
\hline $\begin{array}{l}\mathrm{T}_{6} \text {. Puma super } 75 \mathrm{EW} \text { at } 1.25 \mathrm{~L} \mathrm{ha}^{-1} \\
\text { (30 DAS) }\end{array}$ & 312.6 & 96.6 & 10.3 & 42.6 & 48.6 & 10720 & 4286.7 & 39.9 \\
\hline $\begin{array}{l}\text { T7. Puma super } 75 \mathrm{EW} \text { at } 0.625 \mathrm{~L} \mathrm{ha}^{-} \\
1,50 \% \text { reduced ( } 30 \mathrm{DAS})+ \text { Purple } \\
\text { nutsedge water extract at } 15 \mathrm{~L} \mathrm{ha}^{-1} \\
\text { (45 DAS) }\end{array}$ & 355.6 & 106.3 & 11.5 & 47.3 & 51.0 & 11737 & 4493.0 & 41.9 \\
\hline $\mathrm{T}_{8}$. Hand weeding ( 30 and 45 DAS) & 315.0 & 99.0 & 10.4 & 42.3 & 48.3 & 10717 & 4335.0 & 37.0 \\
\hline $\mathrm{SE} \pm$ & 2.0558 & 1.6185 & 0.4707 & 1.7829 & 1.6726 & 410.85 & 63.483 & 1.7531 \\
\hline LSD 0.05 & 4.4092 & 3.4712 & 1.0085 & 3.8238 & 3.5874 & 881.19 & 136.16 & 3.7600 \\
\hline CV (\%) & 0.86 & 2.28 & 5.98 & 6.06 & 4.55 & 5.58 & 2.42 & 6.05 \\
\hline
\end{tabular}




\section{CONCLUSION AND RECOMMENDATIONS}

It was concluded that application of Puma super $7.5 \%$ EW at $0.625 \mathrm{~L} \mathrm{ha}^{-1}, 50 \%$ reduced (30 DAS) + Purple nutsedge water extract at $15 \mathrm{~L} \mathrm{ha}^{-1}$ (45 DAS) were the most effective for getting higher yield of $\left(4493.0 \mathrm{~kg} \mathrm{ha}^{-1}\right)$ of crop barley. More studied are not only recommended to experiment with the allelopathy potential with this crop barely, but also with other crops. Because if the allelopathic effects are useful and more effective for controlling weeds, the utilization of artificial herbicides can be reduced in order to save the life of many useful species for our crops in the future.

\section{REFERENCES CITED}

Arif, M., Z. A. Cheema, A. Khaliq and A. Hassan. 2015. Organic weed management in wheat through allelopathy. Int. J. Agri. Biol., 17(1): 127-134.

Barberi, P. 2002. Weed management in organic agriculture: are we addressing the right issues. Weed Res., 42: 177193.

Belel, M. D. and R. D. Belel. 2015. Allelopathic effect of leaf and seed extract of nutgrass (Cyperus tuberosus L.) on the germination of beans (Vigna unguiculata L.). Cogent. Food Agri., 1(1): 1-7.

Bhowmik, P. and T. Inderjit. 2003. Challenges and opportunities in implementing allelopathy for natural weed management. Crop. Prot., 22: 661-671.

Bond, W. and A. C. Grundy. 2001. Nonchemical weed management in organic farming systems. Weed Res., 41: 383405.

Bryson, T., K. N. Reddy and T. Molin. 2003. Purple nutsedge (Cyperus rotundus L.) population dynamics in narrow row transgenic cotton (Gossypium hirsutum L.) and soybean (Glycine max L.) rotations. Weed Technol., 17(4): 805-810.

Chachar, Q. I., M. A. Chachar and S. D. Chachar. 2009. Studies on integrated weed management in wheat (Triticum aestivum L.). J. Agric. Technol., 5(2): 405-412.

Cheema, Z. A., S. Ahmad, M. A. Khan and N. Ahmad. 2003. Cotton and weeds response to allelopathic effects of wheat residues and herbicides application under two fertility levels. Pak. J. Weed Sci. Res., 3: 65-67.

Chris, T. L., D. R. Shaw, L. M. Bruce and C. Watson. 2003. Effect of purple (Cyperus rotundus L.) and yellow nutsedge ( $C$. esculentus L.) on growth and reflectance characteristics of cotton and soybean. Weed Sci., 51(4): 557-564.

Didar, J. T. and K. A. Ali. 2016. Study the Allelopathic potential of wild barley as an integrated weed management tool. Zanco, J. Pure Appl. Sci., 28(6): 1-21.

El-Rokiek, K. G., S. A. S. El-Din and F. A. A. Sharara. 2010. Allelopathic behaviour of Cyperus rotundus on both Chorchorus olitorius (broad leaved weed) and Echinochloa crus-galli (grassy weed) associated with soybean. J. Plant. Prot. Res., 50(3): 34-39.

Gomez, K. A. and A. A. Gomez. 1984. Statistical procedures in agricultural Research. Wiley, $2^{\text {nd }}$ ed. New York.

Gupta, O. P. 1998. Weed Management: Principles and Practices. Agro Botanica, Bikaner, India.

Hamayun, M., H. Farrukh, A. Sumera and N. Ahmad. 2005 Allelopathic effect of C. rotundus and $\mathrm{E}$. crus-galli on seed germination, and plumule and radicle 
growth in maize (Z. mays L.). Pak. J. Weed Sci. Res., 11(1-2): 81-84.

He, S. L., S. Q. Wang, Q. Y. Wang, C. Y. Zhang, Y. M. Zhang, T. Y. Liu, S. X. Yang, Y. Kuang, Y. X. Zhang, J. Y. Han and J. C. Qin. 2019. Allelochemicals as growth regulators: A review. Allelopathy J., 48(1): 15-26.

Hansen, P. K., I. A. Rasmussen, N. Holst and C. Andreasen. 2007. Tolerance of four spring barley (Hordeum vulgare L.) varieties to weed harrowing. J. Comp. European Weed Res. Soc., 47: 241-251.

Imen, B., A. Gfeller, M. L. Fauconnier, S. Rezgui, H. S. Amara and P. Jardin. 2014. Allelopathic and autotoxicity effects of barley (Hordeum vulgare L.) root exudates. Pub. Biol. Control., 112.

Inamullah, N. Rehman, N. H. Shah, M. Arif, M. Siddiq and I. Mian. 2011. Correlations among grain yield and yield attributes in maize hybrids in various nitrogen levels. Sarhad J. Agric., 27(4): 531-538.

Jabran, K. 2017. Barley allelopathy for weed control in manipulation of allelopathic crops for weed control. Springer, Brief Plant Sci. Cham., 5763.

Jabran, K., G. Mahajan, V. Sardana and B. S. Chauhan. 2015. Allelopathy for weed control in agricultural systems. Crop Prot., 72: 57-65.

Kamali N., M. R. K. Pour and A. Soleymani. 2014. Studying growth indices and grain yield of barley cultivars at planting dates in Isfahan region. Int. J. Farm Alli. Sci., 3(1): 3544.

Kandhro, M. N., A. K. Jalbani, N. A. Wahocho, G. M. Sahito, M. D. Solangi and Q. D. Jogi. 2016. Laboratory studies on germinability and seedling growth of cotton crop under the allelopathic influence of purple nutsedge. Pak. J. Weed Sci. Res., 22(3): 407-416.

Khaliq, A., A. Matloob, Z. A. Cheema and M. Farooq. 2011. Allelopathic activity of crop residue incorporation alone or mixed against rice and its associated grass weed jungle rice (Echinochloa colona L.). Chilean J. Agri. Res., 71(3): 418-423.

Kong, C. H., P. Wang and X. H. Xu. 2006. Allelopathic interference of Ambrosia trifida with Wheat (Triticum aestivum L.). Agron. Ecosyst. Environ., 119: 416-420.

Kurstjens, D. and M. J. Kropff. 2001. The impact of uprooting and soil-covering on the effectiveness of weed harrowing. Weed Res., 41: 211-228.

Kremer, R. J. and M. Ben-Hammouda. 2009. Allelopathic plants of Barley (Hordeum vulgare L.). Allelopathy J., 24(2): 225-242.

Lemerle, D., G. S. Gill and C. E. Murphy. 2001. Genetic improvement and agronomy for enhanced wheat competitiveness with weeds. Australian J. Agric. Res., 52: 527-548.

Monaco, J. T., C. S. Weller and M. F. Ashton. 2002. Weed science principles and practices. $4^{\text {th }}$ edition. New York. 44. Plant. Sci., 22(3\&4): 367-389.

Mani, V. S., M. L. Malla, K. C. 1973. Gautam and Bhagwndas. Weed killing chemicals in potato cultivation. Indian Farm. 22:17-18.

Murimwa, J. C., J. T. Rugare, S. Mabasa and R. Mandumbu. 2019. Allelopathic effects of aqueous extracts of sorghum (Sorghum bicolor L.) on the early seedling growth of sesame (Sesamum indicum L.) varieties and selected weeds. Int. J. Agron., 1-12. 
Raghvendra, S., R. S. Tomar and $M$. Kumar. 2016. Allelopathy a green approach for weed management and crop production. Int. J. Curr. Res. Biosci. Plant Biol., 3(4): 43-50.

Rao, V.S. 2000. Principles of weed science (2nd Edition). Pp. 72.

Reddy, S. R. 2004. Principles of Crop Production. 2nd Ed. Kalyani Publishers, New Delhi, India. 46 p.

Rasmussen, J. 1991. A model for prediction of yield response in weed harrowing. Weed Res., 31: 401-408.

Rasmussen, J. 1992. Testing harrows for mechanical control of annual weeds in agricultural crops. Weed Res., 32: 267-274.

Ross, M. A. and C. A. Lembi. 2008. Including the ecology and management of invasive plants. Appl. Weed, sci. $3^{\text {rd }}$ Edit. 13-19.

Steel, R. G. D and J. H. Torrie. 1960. Principles and procedures of statistics.

Statistix. 2006. Statistix 8 user guide, version 1.0. Analytical software, P.O. Box 12185, Tallahassee fl 32317 USA. Copyright (C) 2006 by Analytical Software.

Tawaha, A. M., M. A. Turk and G. A. Maghaireh. 2002. Response of barley to herbicide versus mechanical weed control under semi-arid conditions. J. Agron. Crop Sci., 188: 106-112.

Thalooth, T. A., A. Bahr and M. M. Tawfik. 2012. Productivity of some barley cultivars as affected by inoculation under water stress conditions. Elixir Appl. Bot., 51: 10743-10749.

Weston, L.A. and S.O. Duke. 2003. Weed and crop allelopathy. Critical, Review.

Zohary, W. H., J. Pratley, D. Lemerle and T. Haig. 2012. Crop cultivars with allelopathic capability. Weed Res. 39: 171-180. 